regarded as an indication for more careful management, and surgical treatment should be considered.

Further studies are necessary to compare this disease in the United Kingdom with that in Japan. The clinical and morphological findings and limited follow-up data in our patients support the view that the disease is the same in both countries, although we cannot yet estimate the prognosis in the cases diagnosed endoscopically. Nevertheless, all six patients who underwent operation for what were thought to be benign conditions were alive and well after five years. Endoscopy could reasonably be introduced for all high-risk groups of patients, including those with pernicious anaemia, chronic atrophic gastritis, and gastric polyps, those who have undergone gastrectomy, and those over 45 years of age with radiologically negative persistent dyspepsia.

Okabe $^{30}$ emphasises that many cases of carcinoma of the stomach may remain in a superficial stage for a long period. Thus superficial carcinoma can be diagnosed at a younger age than the advanced disease. This should also decrease the incidence of surgical complications and give a better prognosis.

Requests for reprints should be addressed to: Dr G Machado, Rua Almte. Gonçalves 35 apto 501, Copacabana Zc-37, Rio de Janeiro, Brasil.

\section{References}

1 Yamagata, S, et al, in Proceedings of the 3rd World Congress of Gastroenterology, vol 1, p 487. Tokyo, Nissha Printing Co, 1967.

2 Kidokoro, T, in Early Gastric Cancer, ed T Murakami, p 45. Tokyo, University of Tokyo Press, 1971.

${ }^{3}$ Naish, J M, and Read, A E A, Basic Gastro-enterology, p 62. Bristol, John Wright and Sons Ltd, 1974
${ }^{4}$ Brookes, V S, Waterhouse, J A H, and Powell, D J, British Medical fournal, 1965, 1, 1577.

5 Hoerr, S O, Surgery, Gynecology and Obstetrics, 1973, 137, 205.

${ }^{6}$ Prolla, J C, Kobayashi, S, and Kirsner, J B, Archives of Internal Medicine, 1969, 124, 238.

' Gear, M W L, et al, British Fournal of Surgery, 1969, 56, 739.

8 Ashby, B S, Gut, 1974, 15, 512.

9 Machado, G, fornal Brasileiro de Medicina, 1969, 17, 73 (in Portuguese).

10 Machado, G, et al, Aktuelle Gastrologie, 1975, 4, 65.

${ }^{11}$ Davies, J D, Tudway, A J C, and Machado, G, fournal of Clinical Pathology, in press.

12 Murakami, T, in Early Gastric Cancer, ed T Murakami, p 53. Tokyo, University of Tokyo Press, 1971.

13 Sano, R, in Early Gastric Cancer, ed T Murakami, p 81. Tokyo, University of Tokyo Press, 1971

${ }^{14}$ Liguory, C, et al, Mises a four d'Hepato-gastro-enterologie, 1974, 2, 31.

${ }^{15}$ Miller, G, and Kauffmann, M, Proceedings of the 3rd International Congress of Gastrointestinal Endoscopy, p 26. Mexico, Imprenta Madero, 1974.

16 Elster, K, et al, Endoscopy, 1975, 7, 5

17 Machado, G, Gastric Carcinoma. An Endoscopic and Biochemical Appraisal. MD thesis, University of Bristol, 1975.

${ }^{18}$ Machado, G, and Rubens, J, in Anais do XII Congresso Brasileiro e PanAmericano de Cirurgia, p 125. Rio de Janeiro, colégio Brasileiro de Cirurgiões, 1971 (in Portuguese).

19 Ishioka, K, Stomach and Intestine, 1971, 5, 829.

20 Grossman, M I, Gastroenterology, 1971, 61, 635.

${ }^{21}$ Mowat, N A G, Needham, C D, and Brunt, P W, Quarterly fournal of Medicine, 1975, 173, 45.

${ }^{22}$ Montgomery, R D, and Richardson, D P, Quarterly fournal of Medicine, $1975,176,591$.

${ }^{23}$ Salter, R H, Lancet, 1975, 2, 863

$24 \mathrm{Kawai}, \mathrm{K}$, et al, Endoscopy, 1970, 2, 82.

${ }^{25}$ Bachrach, W H, Surgery, Gynecology and Obstetrics, 1962, 114, 69.

${ }^{26}$ Imai, T, and Okubo, T, Stomach and Intestine, 1968, 3, 677.

27 Sakita, T, et al, Gastroenterology, 1971, 60, 835.

28 Doll, R, Scottish Medical fournal, 1964, 9, 183.

29 Ichikawa, H, Clinics in Gastroenterology, 1973, 2, 329.

${ }^{30}$ Okabe, H, in Early Gastric Cancer, ed T Murakami, p 67. Tokyo, University of Tokyo Press, 1971.

\title{
Whole-body in-vivo neutron activation analysis in assessing treatment of renal osteodystrophy with I-alpha-hydroxycholecalciferol
}

\author{
R B NAIK, P GOSLING, C P PRICE, B H B ROBINSON, J T DABEK, D A HEATH, \\ H M JAMES, J A KANIS, R SMITH
}

British Medical fournal, 1976, 2, 79-83

\section{Summary}

Four selected adults with different patterns of osteodystrophy receiving regular dialysis were treated with

\footnotetext{
Renal Unit and Department of Clinical Chemistry, East Birmingham Hospital, Birmingham B9 5ST

R B NAIK, MRCP, honorary senior registrar

P GOSLING, PHD, biochemist

C P PRICE, PHD, principal biochemist

B H B ROBINSON, FRCP, consultant physician

Departments of Experimental Pathology and Medicine, University of Birmingham, Birmingham

J T DABEK, MRCP, research fellow

D A HEATH, MRCP, senior lecturer

H M JAMES, PHD, research fellow

Metabolic Unit, Nuffield Departments of Orthopaedic Surgery and Medicine, University of Oxford, Oxford

J A KANIS, MRCP, research fellow

R SMITH, FRCP, consultant physician
}

1- $\alpha$-hydroxycholecalciferol $\left(1-\alpha-\mathrm{OHD}_{3}\right) \quad 0.5-2 \mu \mathrm{g} /$ day for 10 to 12 months. In two patients, one with osteitis fibrosa and the other with osteomalacia, significant biochemical, radiological, and histological improvements occurred, and total body calcium measured by in-vivo neutron activation analysis increased. In two patients, in whom there were no increases of whole-body calcium, neither biochemical improvement nor healing of bone lesions occurred during the study; in one of these patients the effect of 1- $\alpha-\mathrm{OHD}_{3}$ on bone resorption may have contributed to loss of body calcium and deterioration of bone disease. 1- $\alpha-\mathrm{OHD}_{3}$ may therefore be a valuable adjunct in the treatment of only some patients with renal osteodystrophy. Whole-body in-vivo neutron activation seems to provide a sensitive and non-invasive index of early response to treatment.

\section{Introduction}

Cholecalciferol (vitamin $\mathrm{D}_{3}$ ) is converted in the liver to 25hydroxycholecalciferol, the main circulating form of vitamin D. ${ }^{2}$ Further hydroxylation in the $1-\alpha-$ position to $1-\alpha, 25-$ dihydroxycholecalciferol $\left(1-\alpha, 25-(\mathrm{OH})_{2} \mathrm{D}_{3}\right)$ occurs in the 
kidney. ${ }^{3}$ In patients with renal failure, in whom the production of $1-\alpha, 25-(\mathrm{OH})_{2} \mathrm{D}_{3}$ is impaired, ${ }^{4}$ its administration increases calcium absorption and raises levels of plasma calcium and phosphate. ${ }^{5} 1-\alpha, 25-(\mathrm{OH})_{2} \mathrm{D}_{3}$ has also been shown to heal renal osteodystrophy and improve associated muscle weakness. ${ }^{6}$

$1-\alpha$-Hydroxycholecalciferol $\left(1-\alpha-\mathrm{OHD}_{3}\right)$ is more easily synthesised than $1-\alpha, 25-(\mathrm{OH})_{2} \mathrm{D}_{3}{ }^{7}$ and may be converted to $1-\alpha, 25-(\mathrm{OH})_{2} \mathrm{D}_{3}$ in the intact organism. ${ }^{8}$ Large doses of $1-\alpha-\mathrm{OHD}_{3}(10-30 \mu \mathrm{g} /$ day $)$ given to patients with renal failure resulted in great increases in ${ }^{47} \mathrm{Ca}$ absorption and serum calcium levels. ${ }^{910}$ Smaller doses of $1-\alpha-\mathrm{OHD}_{3}(2 \mu \mathrm{g} /$ day $)$ used for short periods in three dialysed patients were associated with significant increases of intestinal calcium absorption and calcium content of the hand assessed by regional neutron activation analysis. ${ }^{11}$

More prolonged courses of treatment with $1-\alpha-\mathrm{OHD}_{3}$ $(0.5-10 \mu \mathrm{g} /$ day $)$ in three adolescents with renal bone disease not undergoing dialysis resulted in clinical, biochemical, and radiological improvements and a rise in bone mineral content. ${ }^{12}$ In further studies ${ }^{1314}$ treatment with $1-\alpha, 25-(\mathrm{OH})_{2} \mathrm{D}_{3}$ and $1-\alpha-$ $\mathrm{OHD}_{3}$ for up to 12 months in both children and adults reversed the clinical, biochemical, radiological, and histological manifestations of renal osteodystrophy in children. In adults the effects were less consistent and hypercalcaemia was more common.

We have measured the changes in whole-body calcium assessed by neutron activation analysis during treatment with $1-\alpha-\mathrm{OHD}_{3}$ in selected patients with renal osteodystrophy and related these changes to the biochemical, radiological, and histological responses.

\section{Patients and methods}

Four adult patients (table I) treated with intermittent dialysis for chronic renal failure (Cordis Dow or Kiil dialyser for 20-30 hours a week) were studied. All patients had symptomatic renal bone disease and represented the range of renal osteodystrophy seen in this renal unit. None had received vitamin D supplements. The composition of the dialysis fluid was unaltered during the course of the study (calcium $1.6 \mathrm{mmol} / 1(0.8 \mathrm{mEq} / 1)$, magnesium $0.4 \mathrm{mmol} / 1(0.2 \mathrm{mEq} / 1)$; in case 4 calcium was $2.0 \mathrm{mmol} / 1(1.0 \mathrm{mEq} / \mathrm{l}))$.

TABLE I-Details of patients studied

\begin{tabular}{|c|c|c|c|c|c|}
\hline $\begin{array}{c}\text { Case } \\
\text { No }\end{array}$ & $\begin{array}{l}\text { Age } \\
\text { and } \\
\text { sex }\end{array}$ & Renal disease & $\begin{array}{c}\text { Duration of } \\
\text { haemodialysis } \\
\text { (months) }\end{array}$ & Skeletal radiology & Symptoms \\
\hline 1 & $37 \mathrm{~F}$ & $\begin{array}{l}\text { Medullary } \\
\text { cystic disease }\end{array}$ & 36 & $\begin{array}{l}\text { Subperiostea! } \\
\text { erosions, } \\
\text { "rugger jersey" } \\
\text { spine }\end{array}$ & $\begin{array}{l}\text { Loss of height } \\
\text { from vertebral } \\
\text { collapse, severe } \\
\text { skeletal pain } \\
\text { and proximal } \\
\text { myopathy }\end{array}$ \\
\hline 2 & $38 \mathrm{~F}$ & $\begin{array}{l}\text { Chronic } \\
\text { pyelonephritis }\end{array}$ & 105 & $\begin{array}{l}\text { Pseudofractures } \\
\text { pubic rami }\end{array}$ & $\begin{array}{l}\text { Severe skeletal } \\
\text { pain and } \\
\text { proximal } \\
\text { myopathy }\end{array}$ \\
\hline 3 & $27 \mathrm{M}$ & $\begin{array}{l}\text { Alport's } \\
\text { syndrome }\end{array}$ & 96 & $\begin{array}{l}\text { Pseudofractures } \\
\text { of ribs }\end{array}$ & $\begin{array}{l}\text { Severe skeletal } \\
\text { pain and } \\
\text { proximal } \\
\text { myopathy }\end{array}$ \\
\hline 4 & $43 \mathrm{M}$ & $\begin{array}{l}\text { Polycystic } \\
\text { disease }\end{array}$ & 40 & $\begin{array}{l}\text { Subperiosteal } \\
\text { erosions, } \\
\text { "pepper pot" } \\
\text { skull }\end{array}$ & $\begin{array}{l}\text { myopathy } \\
\text { Pain in lower } \\
\text { back and } \\
\text { shoulders }\end{array}$ \\
\hline
\end{tabular}

Whole-body calcium was estimated every four to six months by whole-body neutron activation analysis. ${ }^{15}$ The coefficient of variation in control patients using this method is $3^{\circ}{ }_{0}$. Calcium absorption was assessed using a whole-body counter to measure the retention at seven days of an oral dose of about $5 \mu \mathrm{Ci}$ of ${ }^{47} \mathrm{Ca}$ given in $200 \mathrm{mg}$ of calcium as the chloride. ${ }^{16}$

Plasma calcium, ionised calcium, and inorganic phosphate were measured as previously described. ${ }^{17}$ Blood samples for biochemical estimations were collected during the 12 hours before a dialysis. (Normal ranges are: inorganic phosphate $0 \cdot 80-1 \cdot 45 \mathrm{mmol} / 1$ (2.5-4.5 $\mathrm{mg} / 100 \mathrm{ml})$; plasma calcium $2 \cdot 33-2 \cdot 60 \mathrm{mmol} / 1(9 \cdot 3-10 \cdot 4 \mathrm{mg} / 100 \mathrm{ml})$; ionised calcium $0 \cdot 93-1 \cdot 17 \mathrm{mmol} / 1(3 \cdot 7-4 \cdot 7 \mathrm{mg} / 100 \mathrm{ml})$. The coefficient of variation for ionised calcium was $2.4 \%$.) Activity of alkaline phosphatase was measured by the LKB reaction rate analyser with $x$-napthyl phosphate as substrate. ${ }^{18}$ Bone alkaline phosphatase isoenzyme fraction was determined by using heat stability and L-phenylalanine inhibition techniques. ${ }^{19}$ (The normal adult range for alkaline phosphatase is $17-75 \mathrm{IU} / 1$ and for bone alkaline phosphatase 0-30 IU/1). Parathyroid hormone (PTH) was measured by radio- $\underline{-}$ immunoassay using an antiserum (GP-1) which reacts predominantly to the amino-terminal region of the molecule ${ }^{20}$ (normal level $\left.<0 \cdot 2 \cdot \mu \mathrm{g} / \mathrm{l}\right)$. $\mathrm{D}$ Transiliac bone biopsies were performed under local anaesthesia before $\stackrel{\varrho}{c}$ and four to five months after the start of treatment.

$1-x-\mathrm{OHD}_{3} 2$ : $\mathrm{g}$ daily was given by mouth. Treatment was continued $\overrightarrow{\overline{\vec{O}}}$ for 10-12 months, though the doses were adjusted (see fig 1). At the $\vec{\sigma}$ start of treatment the patients also took a daily supplement of $1 \mathrm{~g}$ 등 calcium as the gluconate. Three patients (cases 1-3) did not receive aluminium hydroxide gel during the period of study but the other $\frac{D}{D}$ was given aluminium hydroxide for pruritus seven months after the $\varrho$ start of treatment, without relief.

\section{Results}

Symptoms-Bone pain was reduced and muscle power improved in cases 1 and 2 (table I). In case 3 treatment was associated with in- 3 creased stiffness and no reduction in bone pain, and in case 4 bone i pain did not improve and pruritus increased.

Biochemical results-Plasma calcium levels rose in three patients, and in case 3 treatment was stopped because of symptomatic hyper-. calcaemia (fig 1). Calcium levels fell thereafter though not to pre- $v$ treatment levels. The patient probably continued to take $1-\alpha-\mathrm{OHD}_{3}$. 응 No consistent changes were seen in plasma phosphate levels. Plasma PTH levels decreased during treatment though they did not fall to $\vec{O}$ normal. ${ }^{4} \mathrm{C}$ a retention at seven days for the four patients is shown in $ᄃ$ table II. After treatment with $1-\alpha-\mathrm{OHD}_{3}$ two patients (cases 1 and 2 ) showed favourable biochemical responses in that calcium absorption $\vec{\theta}$ increased and plasma and bone-derived alkaline phosphatase and PTH decreased. The other two patients showed little change in calcium. absorption, and no decrease in alkaline phosphatase occurred.

TABLE $\mathrm{II}-{ }^{4} \mathrm{C}$ a retention $( \pm S D$ ) seven days before and seven days after starting $1-x-\mathrm{OHD}_{3}$

\begin{tabular}{|c|c|c|c|c|}
\hline Case No: & 1 & 2 & 3 & 4 \\
\hline $\begin{array}{l}7 \text { Days before } \\
7 \text { Days after }\end{array}$ & $\begin{array}{l}25 \cdot 1 \pm 0 \cdot 2 \\
38 \cdot 8 \div 0 \cdot 3\end{array}$ & $\begin{array}{l}15 \cdot 1 \pm 0 \cdot 2 \\
21 \cdot 6 \pm 0 \cdot 2\end{array}$ & $\begin{array}{l}20 \cdot 6 \div 0 \cdot 2 \\
22 \cdot 8 \div 0.3\end{array}$ & $\begin{array}{l}35 \cdot 2: 0.4 \\
36.7+0.3\end{array}$ \\
\hline
\end{tabular}

Total body calcium-There were significant increases of total body calcium in cases 1 and 2 after treatment (fig 2). In the two patients in $\bar{\sigma}$ whom there were no decreases in alkaline phosphatase (cases 3 and $4 ; 3$ fig 2) whole-body calcium did not increase.

$X$-ray changes-There was complete healing of subperiosteal $\frac{\mathrm{O}}{3}$ erosions in case 1 and healing of pseudofractures in case 2 . In case 1 the "rugger jersey" appearance in the spine became more pronounced 을 after treatment. One patient (case 3) developed further pseudofractures $N$ of a phalanx and several ribs. There was no change in the radiological features in case 4 . No patient showed radiological evidence of ectopic deposition of calcium in soft tissues or blood vessels.

Bone biopsy changes - The histological classification of bone biopsy $\mathbb{N}$ specimens taken before and four to five months after the start of $\mathrm{N}$ treatment is shown in table III. In the two patients who showed 0 substantial biochemical improvements (cases 1 and 2) improvements in the histological features of bone were also found. One patient (case 1) showed a decrease in bone fibrosis, but cellular activity was $\mathbb{D}$ not assessed as only a small portion of cancellous bone was taken. The other patient, in whom osteomalacia was present before treatment, $\vec{T}$ showed decreases in osteoid volume and in the maximum number of birefringent lamellae and a decrease in the abnormal osteoid coverage. No changes were observed in cellular activity and no increases in $\stackrel{\mathbb{Q}}{\varrho}$ resorption were found. In the two patients in whom unfavourable $\sigma$ biochemical responses were found (cases 3 and 4) no histological change was observed. Mineralised matrix area did not change in any of the patients studied.

\section{Discussion}

The use of $1-\alpha-\mathrm{OHD}_{3}$ in metabolic bone disease may be associated with increased mineralisation, ${ }^{2122}$ but the drug is 

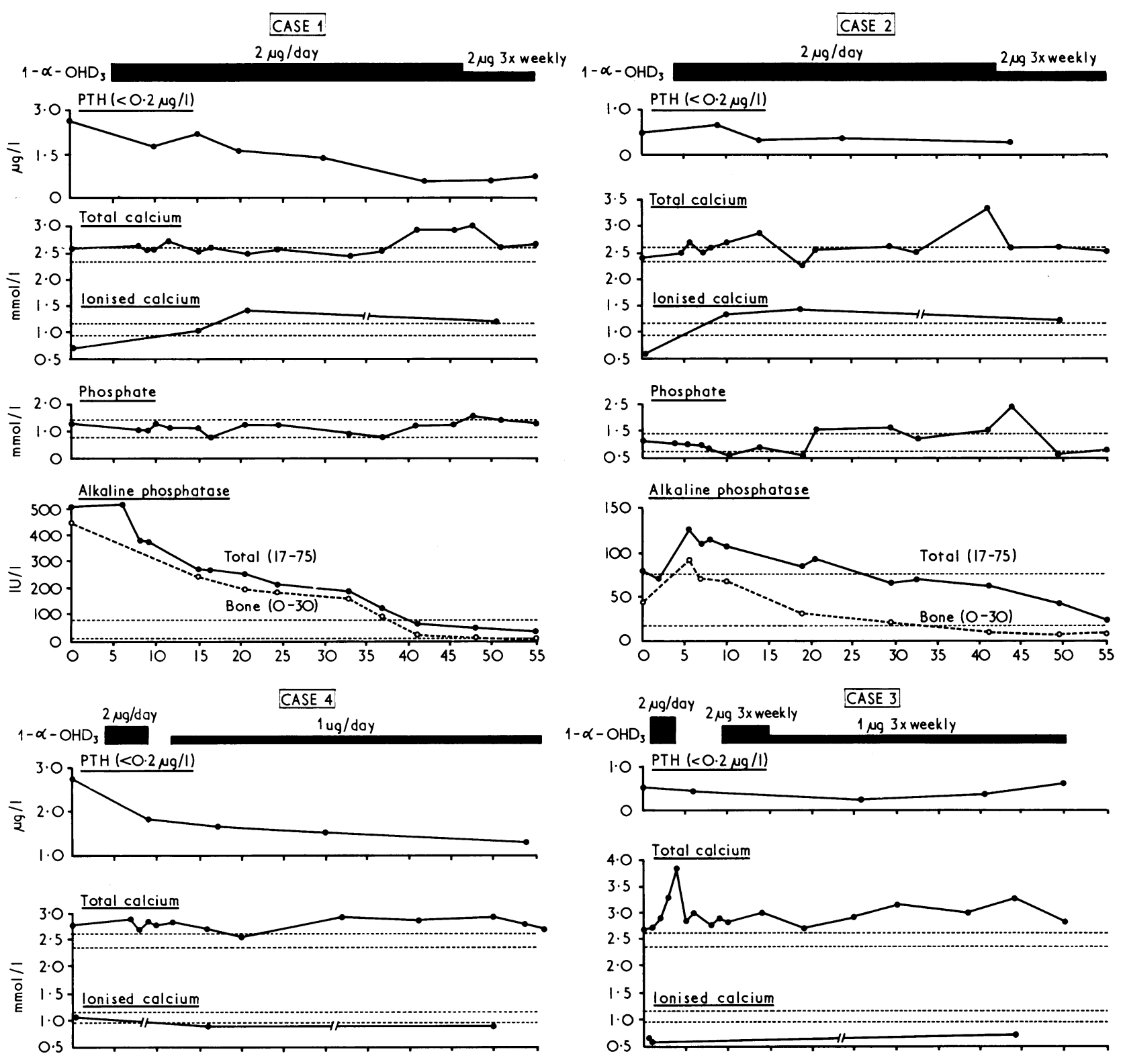

Phosphate $(0.8 \quad 1.45)$

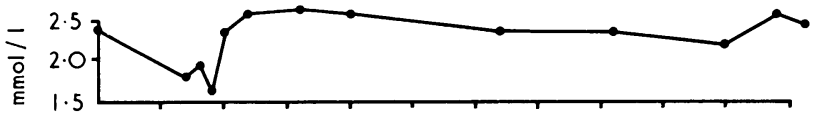

\section{Phosphote}
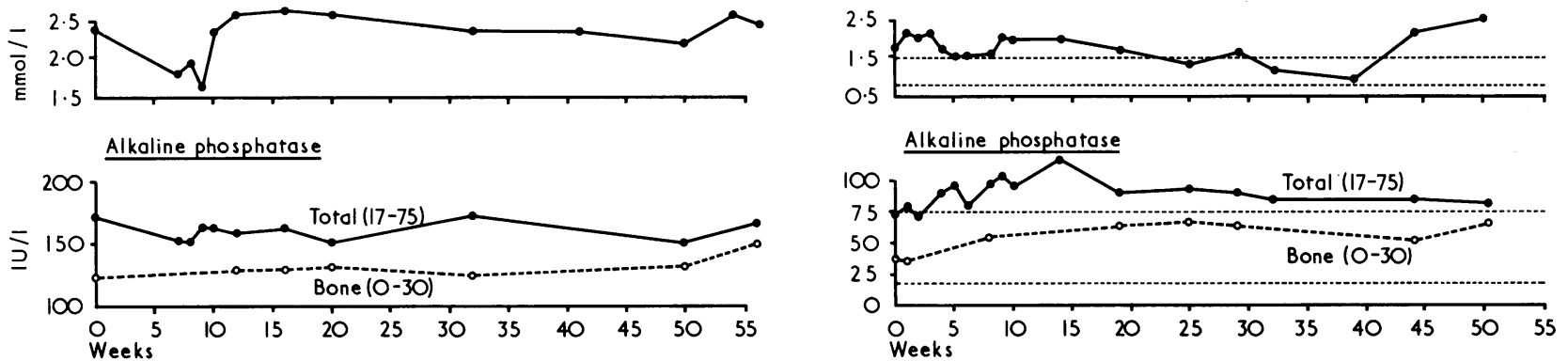

FIG 1-Serial plasma determinations of parathyroid hormone, total and ionised calcium, inorganic phosphate, and total and bone-derived alkaline phosphatase during treatment with $1-x-\mathrm{OHD}_{3}$ in four patients. Dotted lines and values in parentheses represent normal ranges.

Conversion: SI to traditional units-Calcium: $1 \mathrm{mmol} / 1 \approx 4 \mathrm{mg} / 100 \mathrm{ml}$. Phosphate: $1 \mathrm{mmol} / 1 \approx 3 \cdot 1 \mathrm{mg} / 100 \mathrm{ml}$.

also a very potent bone resorbing agent. ${ }^{923}$ The overall balance between bone formation and resorption might be satisfactorily measured by total body neutron activation analysis as this provides the most accurate technique available for measuring relative changes in total body calcium in vivo. ${ }^{24} 25$ This study was carried out to determine whether those patients with renal bone disease who showed favourable responses to $1-\alpha-\mathrm{OHD}_{3}$ also increased their total body calcium as assessed by total body neutron activation analysis. The two patients in whom histo- logical, radiological, and biochemical improvements were seen also showed increases in total body calcium. In contrast, the patients in whom these responses were not seen showed no improvements in calcium content assessed by this technique.

Although treatment with $1-\alpha-\mathrm{OHD}_{3}$ in cases 1 and 2 was associated with decreases in alkaline phosphatase, radiological healing, and early increases in total body calcium, histological improvements were incomplete and no increases occurred in mineralised matrix area. This might suggest either that bone 
TABLE III-Quantitative and qualitative assessment of bone histology before and after four to five months' treatment with 1- $\alpha-O H D_{3}$

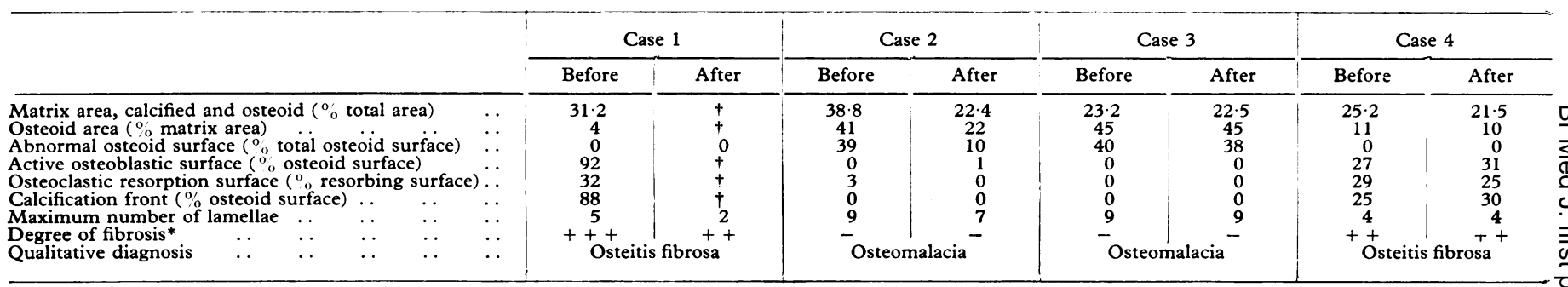

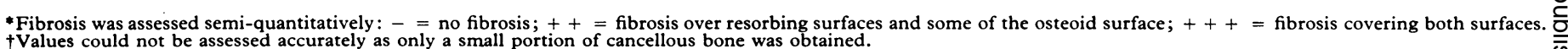

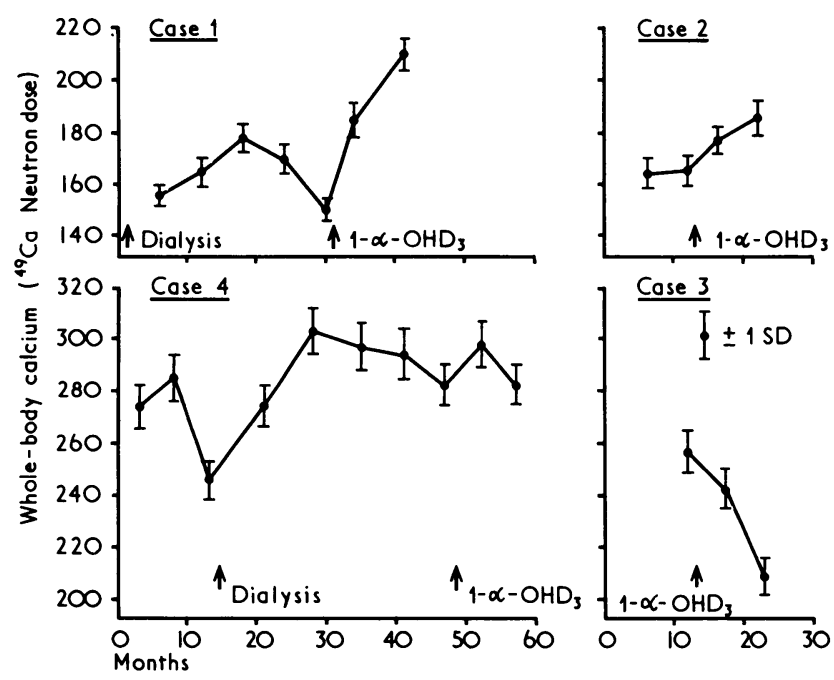

FIG 2-Serial measurements of whole-body calcium $( \pm S D)$ in four patients before and after $1-\alpha-\mathrm{OHD}_{3}$.

healing in the ilium was slow compared with that in other areas and that the interval between biopsies (four to five months) was too brief to observe a maximal effect of $1-\alpha-\mathrm{OHD}_{3}$ or that the increase in total body calcium was due to an increase in soft tissue calcification. The latter possibility seems less likely in view of the large increments of total body calcium seen in our patients and the absence of any evidence of ectopic calcification.

Though large doses of calcium carbonate and calcium phosphate (5-10 g/day) improve calcium and phosphate balance in uraemic patients with chronic renal failure, ${ }^{26}$ our patients were, in contrast, given modest doses of calcium with $1-\alpha-\mathrm{OHD}_{3}$ to supplement their diet. The responses observed were unlikely, therefore, to reflect a response to calcium supplements alone but could be reasonably ascribed to an effect of $1-\alpha-\mathrm{OHD}_{3}$.

Two patients (cases 1 and 2) showed initial increases in ionised calcium during $1-\alpha-\mathrm{OHD}_{3}$ treatment without an associated rise in total calcium, and another patient (case 4), who remained hypercalcaemic, showed a fall in ionised calcium. In view of the low coefficient of variation of the method of measuring ionised calcium, these changes probably reflect changes of protein binding which, in turn, may have been dependent on changes of $\mathrm{pH}, 1-\alpha-\mathrm{OHD}_{3}$, or the dialysis procedure. ${ }^{17}$

If ionised calcium is the primary means by which PTH output is regulated, ${ }^{2728}$ it seems reasonable to suppose that the suppression of PTH secretion with $1-\alpha-\mathrm{OHD}_{3}$ in cases 1 and 2 was associated with an increase in plasma concentration of ionised calcium. In the other patients there was no measurable increase in ionised calcium, and direct inhibition of PTH secretion by the vitamin $\mathrm{D}$ analogue may provide an alternative mechanism. ${ }^{29}$

It is not clear why the other two patients (cases 3 and 4; figs 3 and 4) showed poor responses to treatment. One (case 3) showed several features that suggested progression of bone disease; his symptoms increased, radiological features deteriorated, and there was a loss of whole-body calcium. Although this loss may have been related to the progressive demineralisation 0 seen in some patients on chronic haemodialysis, ${ }^{11} 1-\alpha-\mathrm{OHD}_{3} \vec{\circ}$ may, by increasing bone resorption, have contributed to the $\overrightarrow{\vec{H}}$ deterioration of renal bone disease. The plasma calcium did not $\vec{\omega}$ fall to pretreatment levels despite stopping $1-\alpha-\mathrm{OHD}_{3}$. The $\partial$ prompt fall of plasma calcium to pretreatment levels in other patients with hypercalcaemia ${ }^{11}{ }^{12}$ suggests that self-medication ${ }^{\prime}$ was responsible for the continuing hypercalcaemia in our ${ }^{\circ}$ patient.

The discriminatory value of total alkaline phosphatase activity may be limited in renal osteodystrophy, ${ }^{30}{ }^{31}$ and measurement $\mathrm{O}$ of the bone isoenzyme may provide a more useful index of bone disease, particularly in its early stages. ${ }^{19}$ In case 3 the total 0 activity of alkaline phosphatase was normal before treatment, increased, and then fell during treatment with $1-\alpha-\mathrm{OHD}_{3}>$ (fig 1 ). In contrast, the bone-derived alkaline phosphatase level $\vec{\theta}$ was raised before $1-\alpha-\mathrm{OHD}_{3}$ and increased further during oे treatment. The activity of bone-derived plasma alkaline phos- 0 phatase was raised before treatment in case 2, although total plasma alkaline phosphatase was normal. Treatment was followed by a more rapid fall of bone phosphatase than total alkaline phosphatase and the latter was obscured in part by a rise $\frac{\circ}{\Phi}$ of the liver isoenzyme. These observations suggest that measurement of the bone isoenzyme may also be useful in assessing the response to treatment.

Our experience suggests that $1-\alpha-\mathrm{OHD}_{3}$ has some place, though it is not the panacea in the management of patients with renal bone disease. Hypercalcaemia may complicate treatment and bone lesions may not heal. Those patients (cases 3 and 4) who did not respond to $1-\alpha-\mathrm{OHD}_{3}$ showed no increases in total $\frac{5}{3}$ body calcium. Our findings also suggest that increases of total body calcium as measured by neutron activation analysis are associated with increases of calcium absorption, increases of ionised calcium, suppression of bone alkaline phosphatase, and 윽 radiological and histological improvements. Neutron activation $N$ is a non-invasive technique and if undertaken at intervals may permit early decisions about the suitability of patients for treatment with $1-\alpha-\mathrm{OHD}_{3}$.

We thank Leo Laboratories for supplies of $1-\alpha-\mathrm{OHD}_{3}$; Dr P W Robertson for his help with radiology; Dr C Woods for his help with the histological preparations; and Mr Moxon, of the Birmingham $O$ Ambulance Service, for his continued help in transporting patients $\mathbb{\Phi}$ to and from the cyclotron.

RBN is in receipt of a grant from the Renal Unit Research Fund, $T$ PG a grant from the Birmingham Regional Hospital Board, and JTD an MRC project grant. JAK is in receipt of an MRC clinical research fellowship.

\section{References}

${ }^{1}$ Blunt, J W, DeLuca, H F, and Schnoes, H F, Biochemistry, 1968, 7, 3317.

2 Tucker, G, Gagnon, R E, and Haussler, M R, Archives of Biochemistry, 1973, 155, 47.

${ }^{3}$ Fraser, D R, and Kodicek, E, Nature, 1970, 228, 764.

4 Mawer, E B, et al, Lancet, 1973, 1, 626.

5 Brickman, A S, Coburn, J W, and Norman, A W, New England fournal of Medicine, 1972, 287, 891.

${ }^{6}$ Henderson, R G, et al, Lancet, 1974, 1, 379. 
' Harrison, R G, Lythgoe, B, and Wright, P W, Tetrahedron Letters, 1973, 37, 3649 .

${ }^{8}$ DeLuca, H F, Holick, S A, and Holick, M F, Paper read at the 11 th European Symposium on Calcified Tissues, Elsinore, Denmark, 1975.

${ }^{9}$ Peacock, M, Gallagher, J C, and Nordin, B E C, Lancet, 1974, 1, 385.

1" Chalmers, T M, et al, Lancet, 1973, 2, 696.

1 Catto, G R D, et al, British Medical fournal, 1975, 1, 12.

- Pors Nielsen, S, et al, in Vitamin D and Problems Related to Uremic Bone Diseases, ed A W Norman et al, p 623. Berlin, De Gruyter, 1975.

${ }^{13}$ Henderson, R G, et al, in Calcified Tissues, 1975, ed S Pors Nielsen and E Hiфrting-Hansen. Copenhagen, FADL Publishing Co, in press.

${ }^{14}$ Davie, M W J, et al, Annals of Internal Medicine, 1976, 84, 281.

${ }^{15}$ Chamberlain, M J, and Robinson, B H B, Proceedings of the European Dialysis and Transplant Association, 1970, 7, 126.

${ }^{16}$ Sjoberg, H E, et al, Scandinavian Fournal of Clinical Laboratory Investigation, 1970, 26, 67

1: Gosling, P, Robinson, B H B, and Sammons, H G, Clinical Science, 1975, 48, 521 .
1 Stevens, J, and Thomas, F, Clinica Chimica Acta, 1972, 37, 541.

19 Price, C P, Naik, R B, and Gosling, P, in preparation.

${ }^{20}$ Segre, G V, et al, fournal of Clinical Investigation, 1972, 51, 3163.

${ }^{21}$ Bordier, P, et al, New England Fournal of Medicine, 1974, 291, 866.

22 Lund, B, et al, Lancet, 1975, 2, 1168.

${ }^{23}$ Bordier, $\mathrm{P} \mathrm{J}$, et al, in Vitamin $D$ and Problems related to Uremic Bone Diseases, ed A W Norman et al, p 133. Berlin, De Gruyter, 1975.

${ }^{24}$ Chamberlain, M J, et al, British Medical fournal, 1968, 2, 581.

${ }^{25}$ Cohn, S H, et al, fournal of Laboratory and Clinical Medicine, 1972, 79, 978.

${ }^{26}$ Curtis, J R, et al, Proceedings of the European Dialysis and Transplant Association, 1970, 7, 141.

27 Care, A D, et al, Nature, 1966, 209, 55.

${ }^{28}$ Sherwood, L M, et al, fournal of Clinical Investigation, 1966, 45, 1072.

${ }^{29}$ Chertow, B S, et al, fournal of Clinical Investigation, 1975, 56, 668.

${ }^{30}$ Bishop, M C, et al, Proceedings of the European Dialysis and Transplant Association, 1971, 8, 122.

${ }^{31}$ Moorhead, J F, et al, Annals of Clinical Biochemistry, 1975, 12, 126.

\title{
Comparison of prothrombin complex concentrate and vitamin $K_{1}$ in oral anticoagulant reversal
}

\author{
D A TABERNER, JEAN M THOMSON, L POLLER
}

British Medical fournal, 1976, 2, 83-85

\section{Summary}

A randomised clinical trial was undertaken to compare the value of a factor II, IX, and X concentrate (Prothromplex) with intravenous vitamin $K_{1}(2.5 \mathrm{mg})$ in reversing an overdose of oral anticoagulants. Rapid partial correction of the prothrombin time, partial thromboplastin time, and the clotting factor assays were observed with the concentrate, but these changes were not always sustained. In contrast vitamin $K_{1}$ did not show any great effect at two hours but at 24 hours there was always overcorrection despite the conservative dosage, prothrombin times being shorter than the therapeutic range.

The prothrombin complex concentrate provides a quicker, more controlled but less sustained method of reversing the coumarin defect than vitamin $K_{1}$. But there remains a significant risk of hepatitis even with a preparation for which strenuous efforts have been made to minimise this risk by screening for hepatitis $B$ virus. The risk should be carefully considered before such concentrates are infused in non-urgent conditions.

\section{Introduction}

Clinical experience in British hospitals has shown that patients receiving oral anticoagulant treatment are at particular risk from spontaneous haemorrhage if the British ratio is greater than 5.0. When vitamin $K_{1}$ is used to correct this overdosage patients may become relatively hypercoagulable and possibly resistant to coumarin drugs, which makes their subsequent anticoagulant management difficult. Furthermore, if the patient is suffering life-threatening bleeding more rapid means of correction are required as vitamin $K_{1}$ reversal takes some hours to be effective. The development of prothrombin complex concentrates con-

WHO Collaborating Centre for Anticoagulant Control Regents, Department of Haematology, Withington Hospital, Manchester M20 8LR

D A TABERNER, MRCP, research registrar

JEAN M THOMSON, PHD, principal scientific officer

L POLLER, FRCPATH, MD, consultant haematologis taining vitamin 1-K-dependent clotting factors has offered a possible means of reversing the coumarin defect with small volumes of infusate containing large quantities of clotting factors. A great potential hazard of using these concentrates in patients with recently established thrombosis is, however, the production of disseminated intravascular coagulation (DIC). Reports of the safe use of the concentrates in treating Christmas disease ${ }^{1}$ and liver disease ${ }^{2} 3$ has prompted this study, in which the effectiveness of a prothrombin complex concentrate and vitamin $K_{1}$ in reversing oral anticoagulant overdosage were compared. A product containing factors II, IX, and X only (ProthromplexImmuno; Serological Products Ltd, Dunton Green, Kent) was studied as it is the type of preparation generally available. ${ }^{4}$

\section{Methods}

Eighteen instances of overdoses with nicoumalone (Sinthrome) and two with warfarin were studied. Patients with a British ratio over 5.0 were randomised into two groups. Group 1 (nine patients) received $2.5 \mathrm{mg}$ vitamin $\mathrm{K}_{1}$ intravenously, while group 2 (nine patients) received the concentrate intravenously over 10 minutes, the doses of concentrate varying from 4.7 to 16 units $/ \mathrm{kg}$ body weight with a mean dose of 12 units $/ \mathrm{kg}$. The concentrate contained 0.01-0.05 IU heparin/ unit of factor II. Blood pressure, pulse, and temperature were observed every 15 minutes for one hour after infusion. In both groups blood specimens were taken before and half an hour, two hours, and 24 hours after infusion. No oral anticoagulants were given for 24 hours after infusion.

Laboratory tests-Full blood count; platelet count; measurements of prothrombin time (using British comparative thromboplastin) and partial thromboplastin time (using the proposed international partial thromboplastin time reference preparation); specific assays for factors II, VII, and X; and measurements of thrombin time, fibrinogen, and fibrinogen degradation products (FDP) (by haemagglutination inhibition assay using human red blood cells) were performed on all specimens. Patients receiving the concentrate were screened for the presence of hepatitis B surface antibody. (HBsAb) and antigen ( $\mathrm{HBs} \mathrm{Ag})$ before infusion and every month, when possible, for at least six months. (HBsAb and HBsAg were detected by passive haemagglutination.)

\section{Results}

PROTHROMBIN TIME

Group 1-All patients receiving vitamin $\mathrm{K}_{1}$ showed reversal of the anticoagulant defect, but at 30 minutes there was no appreciable 